\title{
MACH'S SCIENCE EDUCATION, THE PISA STUDY AND CZECH SCIENCE EDUCATION
}

Ernst Mach was not only a physicist with outstanding questions, or a philosopher of science, he was also an excellent educator, both in his theory as well as his own lectures. Unfortunately, this aspect of his epistemology seems rather unknown nowadays [The most notable exceptions have been Bluh (1970), Hohenester (1988), Matthews $(1988,1990,1994)$ and Hoffmann \& Manthei (1991).], though it is therefore all the more worth to revive. His educational epistemology can now be empirically compared by the OECD PISA study as they have been partly implemented in Finland. Also in the Czech Republic, Machian ideas had an influence, but with a focus on experiments rather than the psychology of science education. This difference in focus seems also to result in empirically very different outcomes. For an introduction into the topic, we shall look at a prominent contemporary of Mach, William James, for his opinion on Machian education.

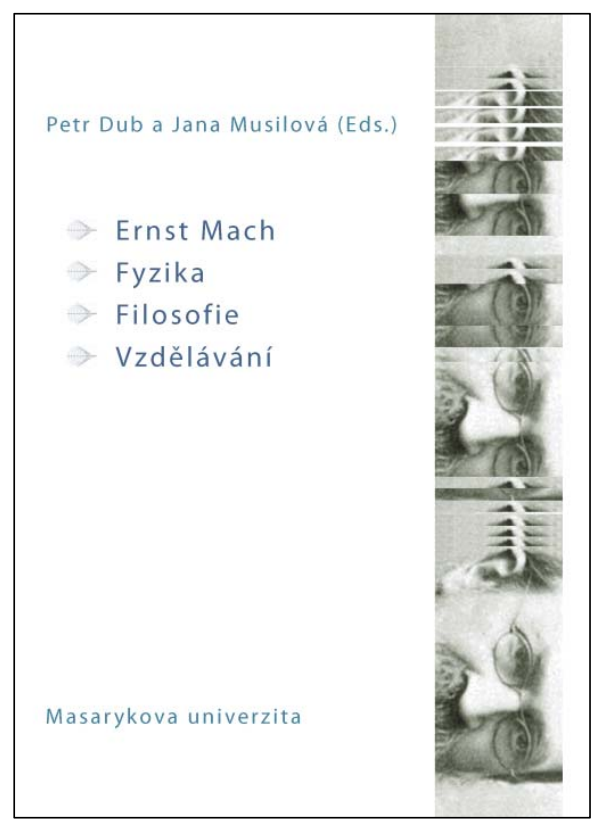

SIEMSEN, Hayo. Mach's Science Education, the PISA Study and Czech Science Education. In: DUB, Petr a Jana MUSILOVÁ. Ernst Mach - Fyzika Filosofie - Vzdělávání. 1. vyd. Brno: Masarykova univerzita, 2010, s. 255-265. ISBN 978-80-210-4808-9. DOI: 10.5817/CZ.MUNI.M210-4808-2011-255. 


\title{
Mach's Science Education, the PISA Study and Czech Science Education
}

\author{
Hayo Siemsen
}

Ernst Mach was not only a physicist with outstanding questions, or a philosopher of science, he was also an excellent educator, both in his theory and in his own lectures. Unfortunately, this aspect of his epistemology seems rather unknown nowadays ${ }^{1}$, though it is therefore all the more worth to revive. For an introduction into the topic, we shall look at a prominent contemporary of Mach, William James, for his opinion on Machian education.

\section{William James' view on Mach's education}

William James is probably more known as a psychologist and philosopher, but he certainly had a strong influence on the current debate on science education because of his successors, especially John Dewey. Dewey's influence on the education system in the US now in turn often serves as the example to emulate in many educational reforms. ${ }^{2}$

William James was not only a close friend of Mach and somebody who admired him greatly, he also stated: „The lecture I heard in Prague from Mach was [...] one of the most artistic lectures I ever heard" (Thiele 1978, p. 169). This strong impression led James to try to emulate Mach's genetic education (letter from 1902):

"I am now trying to build up before my students a sort of elementary description of the construction of the world as built up of 'pure experiences' (in the plural) related to each other in various ways, which are also definite experiences in their turn. (There is no logical difficulty in such a description to my mind, but the genetic questions concerning

\footnotetext{
${ }^{1}$ The most notable exceptions have been Blüh (1970), Thiele, Hohenester (1988), Matthews (1988, 1990, 1994) and Hoffmann \& Manthei (1991).

${ }^{2}$ See for example the Rocard report (European Commission 2007). That this image is not necessarily justified can be seen by the very low results of the US education system in the PISA comparison (far below average, even in the extended study of 2006). Some Finnish educators state that they had to "rescue" their educational system from some US-inspired reforms after WWII.
} 
it are hard to answer.[)] I wish you could hear how frequently your name gets mentioned, and your books referred to [..." (Thiele 1978, p. 173).

James started to develop his own educational ideas and taught psychology for teachers (James 1907, published shortly before his death). Interestingly, in this he did not quote Mach, but this is a fate suffered by many, where Mach's influences became so intuitive that they were not conscious anymore (this actually is closely related to the "genetic" question James had noticed; a larger part of the genesis is not conscious and therefore difficult to analyze). Einstein (1916) in his obituary to Mach called this effect having "sucked-in Mach with the mother's milk". ${ }^{3}$

\section{Mach's educational epistemology in comparison}

But what is Machian educational epistemology? From a Machian point of view, one can distinguish different educational approaches according to their sensualistic and genetic dimensions, as will be elaborated on further. The „pure" physics of for example Planck ${ }^{4}$ or the „pure" logic of Frege tends to abstract as far as possible from the sensual origins of scientific concepts (see Siemsen \& Siemsen 2008), not to speak of any genetic elements. It is the conceptual ",antithesis" of sensualism.

Phenomenalism is relatively more sensualistic. All forms of phenomenalism recognize the sensual origins of phenomena. But depending on the genesis process of the phenomena (initially psychological or logical), the senses and the genesis of sensual interpretation play different roles in the concept. Therefore, Husserl's phenomenalism (to be found for example in Germany), because it presupposes a logical thinking being as its basis, is fundamentally different from for example Eino Kaila' ${ }^{5}$ phenomenalism to be found in Finland) or Hans Freudenthal's ${ }^{6}$ phenomenalism (to be found in the Netherlands). For Kaila, all phenomena are primarily perception-related and for Freudenthal, phenomenalism is didactic, i.e. it starts from folk-concepts of phenomena and develops scientific concepts thereof. In both cases, logic is secondary to the phenomenon and not primary. So Kaila and Freudenthal relative to Husserl follow the order Mach stated for education: psychology is primary to logic. Mach would further have insisted on the sensual elements (instead of more complex perception processes of Kaila and more

\footnotetext{
${ }^{3}$ There are therefore many more "intuitive Machians" than there are "conscious Machians". On the scientific level, intuitive ideas are more difficult to make consistent, because people tend to take them as given. Inconsistencies in the intuitive assumptions of theories are therefore often unconsciously carried over many generations. One central issue of Mach's historio-critical analysis (especially focusing on the idea in nascendi) is to detect them and make them conscious.

${ }^{4}$ This is not to say that Planck had been consistent in defending such a „pure" physics, but he used this concept to attack Mach (see Planck 1908 and 1910, for details see Siemsen, H. 2008).

${ }^{5}$ Kaila was a Gestalt psychologist from Finland and also a philosopher close to the Vienna Circle.

${ }^{6}$ Freudenthal was a Dutch mathematician (topologist and assistant to the intuitionist L.E.J. Brouwer), who later in his life developed a strong interest in education and built up an institute on educational research. For the Freudenthal Institute, see www.fi.uu.nl/fisme/en/.
} 
indirect didactics of Freudenthal ${ }^{7}$ ) and the evolutionary principle of genesis to be the foundational concept of all learning.

\begin{tabular}{|lcc|ccc|c|}
\hline Countries with Rank & $\begin{array}{c}\text { Natural Sciences } \\
\text { Values }\end{array}$ & $\begin{array}{c}\text { Standard } \\
\text { Deviation }\end{array}$ & Rank & $\begin{array}{c}\text { Mathematics } \\
\text { Average } \\
\text { Values }\end{array}$ & $\begin{array}{c}\text { Standard } \\
\text { Deviation }\end{array}$ & $*$ \\
\hline 1 Finland & 563 & 86 & 1 & 548 & 78 & $6 \%$ \\
\hline 4 Netherlands & 525 & 96 & 3 & 531 & 94 & $14 \%$ \\
\hline 7 Germany & 516 & 100 & 11 & 504 & 116 & $14 \%$ \\
\hline 8 Czech Republic & 513 & 98 & 10 & 510 & 128 & $14 \%$ \\
\hline OECD average (of 30) & 500 & 100 & & 500 & 100 & $11 \%$ \\
\hline
\end{tabular}

* Effect of the highest level of parent's education on student performance in science (PISA 2006, in OECD 2008, p. 243).

Table 1: PISA Results 2006 (Source: OECD (2008)).

\section{Educational influences by Mach on the Czech education system}

Did Mach influence Czech education? From current research, two important influences can already be distinguished: First, Mach with his sensualism was certainly in the tradition of Komenský (J. A. Comenius: Orbis Sensuarium Pictus), probably through his father and this influence has been generally strong in the Czech Republic. In this case of course, Mach is a representative of a much older tradition, but he brought sensualism up to date to modern science by incorporating the findings of Charles Darwin into his "sensual elements", Mach's version of Komenský's sensualism. In how far Komenský's sensualism is still applied in current Czech education, still needs to be researched in detail, but the fact that Komenský is still regarded as the pillar of Czech education ${ }^{8}$ implies that there probably is some influence ${ }^{9}$.

Secondly, Mach developed a scientifically important "derivative" of sensualism: experimentation. Mach's experimentalism includes both physical experiments and thought experiments. Both are equally important at different times in the mental model construction process. The physical experimentalism was continued after Mach left Prague at least by Čeněk Strouhal, his former student who became a Professor for Experimental Physics at the Czech University ${ }^{10}$. Even now, maybe because of that influence, the role

\footnotetext{
${ }^{7}$ See below for details.

${ }^{8}$ See for example Pešková et al. (1991) or Kuras (2007).

${ }^{9}$ It has been argued that Komenský's supposed influence is only a recent nationalistic phenomenon, because he at the time being persecuted had no impact. He certainly belonged to an underground protestant order in an officially catholic country, but he was able to publish his educational works even through catholic bishops (see Cornejová 1991) and according to the scarce sources, it seems to have been read. His belief seemingly did not stand in the way of his popularity at the times.

${ }^{10}$ Mach was rector at the time of the split of the Charles University into a Czech and a German university, which Mach deeply regretted.
} 
of experiments (though not necessarily thought experiments) is still very important at the department of physics didactics at the Charles University in Prague. Although one should note here that in the current experimentalism, the experiments are not organized genetically or historically. This aspect of Machian physics education has seemingly not been continued by the Czechs.

Further influences of Mach are probable, but have not been researched yet. ${ }^{11} \mathrm{Ne}-$ vertheless, Mach's ideas on psychology (especially through his close cooperation with Ewald Hering during his time in Prague) do not seem to have survived until nowadays, at least in science education. ${ }^{12}$

\section{Hans Freudenthal and the PISA-study}

The so called PISA (Program for International Student Assessment) study from the OECD is currently the largest empirical study comparing different national education systems. It has its epistemological basis ${ }^{13}$ in the criticism of Freudenthal $(1975)^{14}$ on the first approaches of the OECD to education. The OECD at the time was strongly influenced by the Bourbaki group's ideas of a "new maths", i.e. the introduction of set theory into schools and submission of all mathematics to a rigorous formalism from the point of view of set theory. These ideas later seem to have led to the TIMSS study (which is certainly much more logicistic than the PISA study).

Also from Freudenthal's approach to didactics in physics ${ }^{15}$, one can see that Freudenthal is explicitly phenomenological and real-life-situation oriented, rather than purely logical. On a Mach-Husserl phenomenology scale, he can certainly be classified more on the Machian side. ${ }^{16}$ Freudenthal asked for explication of implicit assumptions in pedagogy in order to be able to criticize them and include them into the teaching process, instead of assuming them to be already present in the learner. Therefore, the PISA

\footnotetext{
${ }^{11}$ For example the popular physics books by Ya. Perelman from Russia (Physics for Entertainment), which have seemingly influenced several physicists in the Czech Republic in their youth and which are written in a strongly Machian spirit (probably due to Bogdanov's promotion of Mach's ideas in Russia). Also the question of Machian successors in the Czech Republic after Mach left has not been extensively researched yet.

${ }^{12}$ Psychology and especially Machian-related psychology does not seem to play any role in physics didactics today, at least at the Charles University.

${ }^{13}$ The approach included also other international influences, but Freudenthal has been very important in the process, see for example De Lange (2006). The term "literacy" - what PISA claims to measure is (among other sources) explicitly based on Freudenthal's critique and terminology (see OECD 1999, p. 41).

${ }^{14}$ For the historical details, see Siemsen \& Siemsen (2008a). Freudenthal's criticism built on the criticism from Wittenberg (1965).

${ }^{15}$ See for example at the Freudenthal Institute www.fi.uu.nl/fisme/en/.

${ }^{16}$ Freudenthal even explicitly quotes Mach as the - in his view leading - authority on historical and epistemological phenomenology in mechanics. But he seemingly overlooks Mach's didactical aspects as well as the general scientific ones (Freudenthal 1993, p. 73).
} 
study can be regarded as a relatively good statistical proxy for Machian phenomenology as opposed to Husserlian, at least better than the TIMSS study and "normal" logical (non-sensualist) tests used in most German and Czech schools. Machian genetic teaching is not tested thereby (Siemsen 1981).

\section{The PISA study and its empirical results}

The results of the PISA study in mathematics and the natural sciences can be seen in Table 1. ${ }^{17}$ The numbers might not look impressive at first sight, but the (roughly 50 points) difference between Germany or the Czech Republic and Finland on the other side translates into a minimum of $3 / 4$ of a year of school and this in just five years of secondary school. If the process is assumed to be linear, this figure would nearly double until the end of secondary school, if the process is exponential, it could be much worse.

What is the reason for this difference? Of course there are probably many. So we shall focus on what might be the most important factors from the Machian perspective: First of all, one notices that depending on the sensualist-phenomenology scale, the countries follow roughly in the order of their sensualism as briefly outlined before: Finland is the most sensualist country in their educational epistemology (influenced by Kaila's gestalt psychology), while the Netherlands (influenced by Freudenthal's didactical phenomenology) are still good, but further behind and better in Freudenthal's original field of mathematics. Germany (mostly influenced by Husserlian logical phenomenology and Planck's physicalism) and the Czech Republic are further behind. Actually, these effects were even more pronounced in the earlier PISA studies (2003 and 2000). This on the one hand is due to the effect of more low-level countries joining the study (thereby lowering the average) but also points towards an adaptation effect of some countries "training" their students in the PISA-type questions (which certainly is true in Germany, where a direct mention of PISA has now been included in many curricula).

So what are the main differences in the data between the countries mentioned? One of the most obvious differences is the standard deviation, which is much lower in Finland. How do the Finns achieve this? As Table 2 shows, they (as the only country) manage to „push the laggards" 18 , i.e. they shift the low-achieving students into higher levels. While other countries optimize their education for the "elite" (i.e. the top 20\%), the Finns optimize it for the average student (the other $80 \%$ ). ${ }^{19}$

\footnotetext{
${ }^{17}$ For brevity reasons and also because of the main scope of prior research, the analysis will currently only include Finland, the Netherlands, the Czech Republic and Germany.

${ }^{18}$ The term "laggards" is fundamentally misleading, as they can suddenly excel with other teaching methods (Wertheimer 1912).

${ }^{19}$ The Finns have, for example, an elaborate system of helping students who have trouble following the normal lectures. They are not taken away into separate courses (sieved out), but get separate courses additional in order to focus on their individual learning problems. There are several intensity levels of this system.
} 
This leads us to the central question, why are some students top, while others are lagging behind? PISA also measures the so called "literacy", which means the understanding of concepts and terms (not depicted in the Tables). In general, the statistical result is: the higher the literacy, the better the science and mathematics results. So one of the problems is that in tests (and in the lessons), students do not understand the terminology, although they often understand a larger part of the concept, if one lets them describe it in their own terms ${ }^{20}$. In logicistic education systems, scientific terminology tends to be introduced very briefly as definitions (which in turn often use unknown scientific terminology). Such definitions are necessarily very abstract and little connected to the sensual experience of the students. But if they are not connected to experience, they can only be memorized, but not understood (what A.N. Whitehead called ,inert ideas"). If they are introduced very fast (and often without an example from daily life), even the good students often have not enough time to bridge the cognitive gap. At home, only educated parents can help their children with this problem.

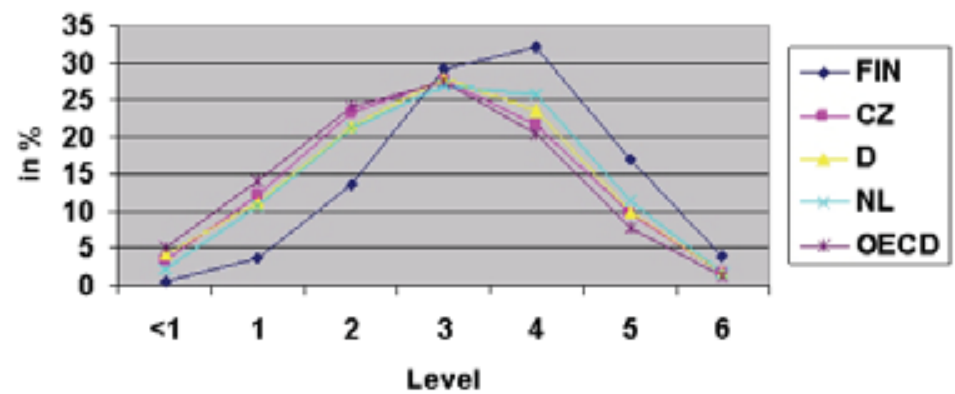

Table 2: Proficiency Level in Science in PISA 2006 (Source: OECD (2008)).

This leads to the second interesting statistical difference (which takes us back to the last column in Table 1), which is especially to be found in Germany and the Czech Republic: the influence of parents' education on school performance. With $14 \%$ each (this taking into account only the very top educated parents), it is more than double the figure for Finland. So the "good" school children in Germany and the Czech Republic (who these systems profess to especially promote) actually seem to be due to what the parents teach them, and not so much on what the school teaches them.

From a Machian point of view, all the above empirical observations point ${ }^{21}$ towards a central problem in some educational systems: A fundamental lack of understanding of some basic principles by the students. Once the gap is there, it is never recovered

\footnotetext{
${ }^{20}$ This can easily be tested. The results of these tests tend to be quite univocal: The language of the teacher is often not the language of the students.

${ }^{21}$ This is of course at the current level of research only a hypothesis, but certainly an interesting one to pursue more in detail.
} 
later. All later knowledge piled on top of this lacking basis is built on sand and soon forgotten. ${ }^{22}$

But what is Mach's suggestion to avoid this problem? How should teaching of scientific concepts be more adapted to the psychology of the learners?

\section{Mach's science education}

For brevity reasons, I will not be able to explicate Mach's educational epistemology ${ }^{23}$ in detail, but its main points are a genetic and monistic approach. All science is one and specialization, especially when it is introduced too early, is a betrayal rather than a service to science education (Wittensberg 1968). A phenomenon has physical, chemical, mathematical and maybe biological aspects. Looking at only one aspect will destroy the unity of the phenomenon, i.e. the important links between aspects. For example the sun in the physics lesson will not be the same sun the son or daughter of the farmer sees rising above the field. The light of the sun in the physics lesson will in the mental model of the child not be the result of a chemical reaction and it will have nothing to do with photosynthesis in biology.

In contrast to his predecessor ${ }^{24}$ Herbart, Mach developed his epistemology after Darwin published his "Origin of the Species" in 1859. Therefore, his concept of "genesis" is fundamentally different from the one used by Herbart and his successors. Genesis is a complex phenomenon and it takes different forms: phylogenesis, ontogenesis, cultural genesis, etc. Also in science and for the foundation of our thought processes, all of these forms might be important to take into account. Our body, so also our senses, nervous system or brain evolved in a certain way (e.g. not all senses have developed at the same time and therefore have different connectivity), our bodily development proceeds according to some biological guidelines (genes), we live in a certain environment, making specific experiences and we grow up in certain culture in which certain concepts are transmitted (often intuitively, i.e. not consciously), etc. Science thereby becomes just a specific development of culture.

This genetic concept for example implies that the main part (and especially the early ${ }^{25}$ part) of learning is unconscious, i.e. it cannot be made conscious. If unconscious elements of concepts are not built through mental adaptation, any efforts at conscious teaching, which are not including the unconscious elements, will not succeed. This is especially problematic when a part of a class has been taught these elements at home, but another part has not. The teacher can have the impression that some students are

\footnotetext{
${ }^{22}$ This can easily be tested by asking „simple“, but fundamental questions, as Wagenschein (1970) and Arons (1997) have shown for Germany and the USA respectively.

${ }^{23}$ Unfortunately, Mach did not write a central book on this topic, but his ideas have to be collected from many footnotes and rare articles, which is probably one reason why this topic has been so strongly neglected.

${ }^{24}$ In science education.

${ }^{25}$ This means early in concept formation, not early in age.
} 
„just stupid", while the main problem is that he is trying to build on a basis, which simply in many cases does not exist. ${ }^{26}$ Therefore any science education epistemology abstracting from the psychology of the learner can run into great difficulties. ${ }^{27}$

Machian genesis for example leads to the following principles in education:

- Always start with the „immediately given“ phenomena, even for older students

- Avoid early abstraction in concept and mental model formation at all cost

- Children are able to form concepts with any precision at any age, if the genetic basis of these concepts is properly laid

- Work on internal inconsistencies (adaptation of perceptions to the thoughts and the thoughts to each other)

- Science has three historical forms: first in the thoughts of some researchers, then in a written form as part of the scientific culture and thirdly, being popularized, becoming part of the general culture. Each of these three steps requires a strong mental effort (but the last one is too often neglected)

- No science can ever be final; we have to live with an unfinished world view.

Mach stated his genetic idea of learning nicely in the following passage (Mach 1923/1987, No. 17): „Nobody who concerned himself with scientific thinking will state [suggestions based on a ,subject matter model']. Thoughts can be stimulated and fertilized, like a field is fertilized by sunshine and rain.

Thoughts however cannot be rushed out and not drilled out, certainly not through recipes, by amassing subject matter and lessons. They want to grow voluntarily. Thoughts can just as little be accumulated above a certain measure in a head, as the yield of a field can be increased unlimitedly. I believe that the subject matter for an appropriate education, which jointly must be offered to all pupils of a preparatory school, is very modest $[\ldots]$.

If a young human is not to come dulled to the university, if he is not to have spent his vitality in the preparatory school, which he thereat still has to collect, an important

\footnotetext{
${ }^{26}$ Interestingly, in Machian education, the formerly good students tend to become "second best", while formerly average students suddenly excel. This effect (see also Siemsen 1981), which has also been experimentally observed to exist in the Czech Republic, implies that current education systems supporting especially ,elite" students, often do not focus on the best students (in terms of those that have understood best), but on those best adapted to what the teacher wants to hear (parroting-back effect).

${ }^{27}$ Therefore the former affirmation that Mach's psychology seems to have been lost in Czech science teaching culture after Mach left, might to a larger part have contributed to the PISA effect. But if this would be the main factor, it might not require so many resources to reinstitute.
} 
change here has to occur. Even if I refrain here from stating the harmful physical consequences of physical overburdening, already the disadvantages for the intellect appear to me equally horrible. I do not know of anything more terrible than the poor humans, who have learnt too much."

\section{References}

[1] O. Blüh: Ernst Mach - His Life as a Teacher and Thinker. In: Ernst Mach: Physicist and Philosopher. (Eds.: R. Cohen, R. Seege). Boston Studies in the Philosophy of Science, Vol. VI, D. Reidel Publishing Company, Dordrecht 1970, 1-22.

[2] A. Hohenester: Ernst Mach als Didaktiker. In: Ernst Mach: Werk und Wirkung (Eds.: R. Haller, F. Stadler). Verlag Hölder-Pichler-Tempsky, Vienna 1998, 138166.

[3] M. R. Matthews: Ernst Mach and Thought Experiments in Science Education. Research in Science Education 18 (1988), 251-257.

[4] M. R. Matthews: Ernst Mach and Contemporary Science Education Reforms. International Journal of Science Education 12 (1990), 3, 317-325.

[5] M. R. Matthews: Science Teaching: The Role of History and Philosophy of Science. Routledge, London 1994.

[6] D. Hoffmann, W. Manthei: Ernst Mach als Schulphysiker, Didaktiker und Bildungstheoretike: In: Ernst Mach - Studien und Dokumente zu Leben und Werk (Eds.: D. Hoffmann, H. X. Laitko). Deutscher Verlag der Wissenschaften, Berlin 1991, 279-314.

[7] W. James: Talks to Teachers on Psychology. Holt, New York 1907.

[8] J. Thiele: Wissenschaftliche Kommunikation. Die Korrespondenz Ernst Machs. Henn, Kastellaun 1978.

[9] European Commission (2007) Science Education Now: A Renewed Pedagogy for the Future of Europe, downloadable at http://ec.europa.eu/research/science-society/Cited 20 Apr 2008.

[10] A. Einstein: (1916 / 1923 / 1987) Ernst Mach, reprint in Ernst Mach: Populärwissenschaftliche Vorlesungen, 5th edition. Barth, Leipzig 1923. Böhlau, Wien, Köln, Graz 1987, 641-643. 
[11] M. Planck: Die Einheit des Physikalischen Weltbildes. In: Max Planck: Ein Leben für die Wissenschaft 1858-1947 (Ed.: J. L. Heilbronn). Hirzel, Stuttgart 1908; 1988a, 301-313.

[12] M. Planck: Zur Machschen Theorie der Physikalischen Erkenntnis - Eine Erwiderung. In: Max Planck: Ein Leben für die Wissenschaft 1858-1947 (Ed.: J. L. Heilbronn). Hirzel, Stuttgart 1910, 1988b, 314-318.

[13] H. Siemsen: The Mach-Planck debate revisited: Democratization of science or elite knowledge? Forthcoming in the Journal for the Public Understanding of Science, 2009.

[14] H. Freudenthal: Why to Teach Mathematics So as to Be Useful. Educational Studies in Mathematics 1, (1968), 1/2, Proceedings of the Colloquium "How to Teach Mathematics So as to Be Useful", 3-8.

[15] H. Freudenthal: Pupil's achievements internationally compared - The IEA. Educational Studies in Mathematics 6 (1975), 127-186.

[16] H. Freudenthal: Didactical Phenomenology of Mathematical Structures. D. Reidel Publishing Company, Dordrecht 1993.

[17] H. Freudenthal: Thoughts on Teaching Mechanics Didactical Phenomenology of the Concept of Force. Educational Studies in Mathematics 25 (1993), 1/2, 71-87.

[18] J. Pešková, J. Cach, M. Svatoš (Eds.): Homage to J. A.Comenius. Karolinum, Praha 1991.

[19] B. Kuras: Restoring Comenius. Ideal, Praha 2007.

[20] I. Čornejová: The Jesuit School and John Amos Comenius: In: Homage to J. A. Comenius (Eds.: J. Pešková, J. Cach, M. Svatoš). Karolinum, Praha 1991.

[21] E. Mach: Über das psychologische und logische Moment im Naturwissenschaftlichen Unterricht. In: Zeitschrift für den physikalischen und chemischen Unterricht 4 (1890), 1, 1-5.

[22] J. de Lange: Mathematical Literacy for Living from OECD-PISA Perspective. Proceedings of the Symposium on International Cooperation "Innovative Teaching Mathematics through Lesson Study", 2006.

[23] OECD (1999) Measuring Student Knowledge and Skills. http://www.oecd.org. Cited 14 Jan 2008. 
[24] OECD (2003) PISA 2003 Assessment Framework: Mathematics, Reading, Science and Problem Solving Knowledge and Skills. http://www.oecd.org. Cited 14 Jan 2008.

[25] OECD (2006a) Education at a Glance 2006 - Executive Summary. http://www. oecd.org. Cited 21 Aug 2007.

[26] OECD (2006b) Assessing Scientific, Reading and Mathematical Literacy - A framework for PISA 2006. http://www.oecd.org. Cited 14 Jan 2008.

[27] OECD (2008) PISA 2006 Volume 2: Data. http://www.oecd.org. Cited 6 Jun 2008.

[28] H. Siemsen, K. H. Siemsen: Ideas of Ernst Mach Teaching Science. Gh. Asachi University, Cetex, lasi, 5th Int. Seminar on Quality Management in Higher Education (QMHE 2008), Tulcea (RO) 2008.

[29] H. Siemsen, K. H. Siemsen: Resettling the Thoughts of Ernst Mach and the Vienna Circle to Europe - The cases of Finland and Germany. Science and Education 18, 299-323.

[30] A. I. Wittenberg: Priorities and Responsibilities in the Reform of Mathematical Education. An Essay in Educational Metatheory. L'Enseignement mathématique 11 (1965), 287-308.

[31] M. Wagenschein: Was bleibt? In: J. Fluegge, Zur Pathologie des Unterrichts. Klinkhardt, Bad Heilbrunn 1970, 74-91.

[32] A. B. Arons: Teaching Introductory Physics. John Wiley \& Sons, New York 1997.

[33] K. H. Siemsen: Genetisch-adaptiv aufgebauter rechnergestützter Kleingruppenunterricht - Begründungen für einen genetischen Unterricht. Peter D. Lang, Frankfurt und Bern 1981.

[34] M. Wertheimer: Über das Denken der Naturvölker I: Zahlen und Zahlgebilde. Zeitschrift für Psychologie 60 (1912), 321-378; reprinted in Drei Abhandlungen zur Gestalttheorie (Erlangen, 1925), 106-161.

[35] A. I. Wittenberg: The Prime Imperatives: Priorities in Education. Clarke, Irwin \& Company, Toronto Vancouver 1968. 